\title{
Gall inducing arthropods from a seasonally dry tropical forest in Serra do Cipó, Brazil
}

\author{
Marcel Serra Coelho ${ }^{1}$, Emmanuel D. Almada ${ }^{1}$, G. Wilson Fernandes ${ }^{1}$, Marco Antonio A. Carneiro ${ }^{1,2}$, \\ Rubens M. dos Santos ${ }^{3}$, André V. Quintino ${ }^{1}$ \& Arturo Sanchez-Azofeifa ${ }^{4}$
}

${ }^{1}$ Laboratório de Ecologia Evolutiva \& Biodiversidade, Universidade Federal de Minas Gerais, Caixa Postal 486, 30161-970 Belo Horizonte-MG, Brasil.gwilson@icb.ufmg.br

${ }^{2}$ Universidade Federal de Ouro Preto, Campus Morro do Cruzeiro, 35400-000 Ouro Preto-MG, Brasil.

${ }^{3}$ Programa de Pós Graduação em Engenharia Florestal, Universidade Federal de Lavras, 37200-000 Lavras-MG, Brasil.

${ }^{4}$ Earth and Atmospheric Sciences Department, Universty of Alberta, Edmonton, Alberta, T6G2E3, Canada.

\begin{abstract}
Gall inducing arthropods from a seasonally dry tropical forest in Serra do Cipó, Brazil. Highly diverse forms of galling arthropods can be identified in much of southeastern Brazil's vegetation. Three fragments of a Seasonally Dry Tropical Forest (SDTF) located in the southern range of the Espinhaço Mountains were selected for study in the first survey of galling organisms in such tropical vegetation. Investigators found 92 distinct gall morphotypes on several organs of 51 host plant species of 19 families. Cecidomyiidae (Diptera) was the most prolific gall-inducing species, responsible for the largest proportion of galls $(77 \%)$ observed. Leaves were the most frequently galled plant organ (63\%), while the most common gall morphotype was of a spherical shape (30\%). The two plant species, Baccharis dracunculifolia (Asteraceae) and Celtis brasiliensis (Cannabaceae), presented the highest number of gall morphtypes, displaying an average of 5 gall morphotypes each. This is the first study of gall-inducing arthropods and their host plant species ever undertaken in a Brazilian SDTF ecosystem. Given the intense human pressure on SDTFs, the high richness of galling arthropods, and implied floral host diversity found in this study indicates the need for an increased effort to catalogue the corresponding flora and fauna, observe their intricate associations and further understand the implications of such rich diversity in these stressed and vulnerable ecosystems.
\end{abstract}

KEYWORDS. Biodviersity; biogeography; host plant family; herbivory; Insect galls; Richness.

RESUMO. Artrópodes indutores de galhas em Floresta Sazonal Tropical Seca da Serra do Cipó, Brasil. Artrópodes indutores de galhas são muito ricos em espécies nas formações vegetais no sudeste do Brasil. Três fragmentos de Floresta Sazonal Tropical Seca (FSTS) foram selecionados nas montanhas do sudeste da cadeia do Espinhaço para a primeira pesquisa de organismos indutores de galhas nesse tipo de vegetação. Encontramos 92 morfotipos distintos de galhas em vários órgãos de 51 espécies de plantas hospedeiras pertencentes à 19 famílias. A maioria das galhas (77\%) foi induzida pela família Cecidomyiidae (Diptera). A folha foi o órgão mais atacado (63\%), enquanto o morfotipo mais comum foi a forma esférica (30\%). As espécies hospedeiras que apresentaram um maior número de morfotipos de galhas foram Baccharis dracunculifolia (Asteraceae) e Celtis brasiliensis (Cannabaceae), cada uma com cinco morfotipos de galha. Este é o primeiro estudo com galhas induzidas por artrópodes em áreas FSTS no Brasil. Dada a intensa pressão antrópica nas áreas de FSTS, a alta riqueza encontrada nesse estudo de artrópodes indutores de galhas aponta a necessidade de um maior esforço para se compreender a diversidade desses ecossistemas.

PALAVRAS-CHAVE. Biodiversidade; biogeografia; família de plantas hospedeiras; herbivoria; insetos galhadores; riqueza.

Galls are produced by an abnormal increase in the number and/or size of plant cells resulting in the formation of a symmetrical structure(s) on one or more organs of a host plant (Mani 1964; Raman 2007). Three influences give rise to the specific gall phenotype, namely: the genotype of the arthropode, the genotype of the host plant and general environmental factors such as heat, drought, soil composition, etc. (Weis et al. 1988). From an evolutionary perspective, insect galls can be regarded as extended phenotypes of the inducers, unique in that the parasitic arthropod induces a characteristic adaptation within the host plant that benefits itself and its offspring. Galls developed by host plants provide gall-inducers a refuge for their larvae that supplies tissues of high nutritional quality and protection from harsh environmental conditions and from natural enemies (Price $e t$ al. 1986; 1987; Nyman \& Julkunen-Tiitto 2000; Stone \& Schönrogge 2003).
Galls are induced by an enormous array of organisms, but those induced by insects are the most speciose (Mani 1964). Recent galling richness estimates suggest a low of 21,000 to as many as 211,000 gall-inducing arthropod species on earth (Espírito-Santo \& Fernandes 2007). Only a very small fraction of these phenotypes have been catalogued in a systematic manner. Galls induced by insects are argued to be especially abundant in plant species found in hot and dry habitats, and also are numerous in as sclerophyllous host plants in both tropical and temperate regions (Fernandes \& Price 1988, 1991; Lara \& Fernandes 1996; Price et al. 1998).

The Neotropics, rupestrian fields and Cerrado (savanna) were identified as vegetation types with the highest richness of galling insects in the world (Lara \& Fernandes 1996). Although many surveys were performed in various Brazilian biomes [e.g., Atlantic Rainforest (Fernandes et al. 2001; Mendonça 2007), Cerrado (Fernandes et al. 1988; Gonçalves- 
Alvim \& Fernandes 2001; Maia \& Fernandes, 2004), Pantanal (Juliao et al. 2002), Amazonian rain forest (Julião et al. 2005), Subtropical Seasonal Forest (Dalbem \& Mendonça (2006); Restinga (Maia 2001, 2005; Maia et al. 2002; Mendonça 2007; Oliveira \& Maia 2005)] we are not aware of any studies performed in the Brazilian Seasonally Tropical Dry Forest (STDF). These forests are essentially tree-dominated, closed canopy, fertile soil ecosystems, dominated by the Fabaceae and Bignoniaceae families (Pennington et al. 2000). It should be noted that patterns of composition and species dominance can vary even among STDFs limited to the Minas Gerais state (Meguro et al. 2007). Dry forests shed at least 50\% of their leaves during the dry season, depending upon soil conditions (Ribeiro \& Walter 1998; Sánchez-Azofeifa et al. 2005). Brazilian dry forests occur in the Cerrados of central Brazil in areas of fertile soils (Ratter et al. 1978), and in the Brazilian states of Minas Gerais, Goias, Bahia and border regions of the Amazon (Rizzini 1997; Nascimento et al. 2004). When on limestone, the dry forests are called Seasonally Deciduous Forest of Slope (Nascimento et al. 2004). Refer to Prado (2000) for a review of the origin and distribution of this unique South American ecosystem.

In this study we will describe the galls induced in host plants by arthropods (insects and mites) inherent to the natural fragments (or islands) of dry forests rooted in a limestone substrate and located in southeastern Brazil at the base of Serra do Cipó mountain. This work is part of our efforts to describe 1) the natural history of galling insects; 2) the galls produced by these insects and their host plants in different Brazilian vegetations, particularly in the Seasonally Tropical Dry Forests of the Americas.

\section{MATERIAL AND METHODS}

Samples were obtained from various plant specimens found in dry forests covering limestone outcrops in Serra do Cipó, Municipality of Santana do Riacho, MG, in southeastern Brazil. The Serra do Cipó is located in the southern portion of the Espinhaço Range and is dominated by Cerrado and rupestrian field vegetation (Eiten 1978; Giulietti et al. 1987). Because most of the dry forests in the region have been subject to disturbances induced by man (cattle, fire, logging, mining), only three fragments of the selected STDF were deemed acceptable for this study: Rancho Cipó (1) coordinates $43^{\circ}$ 36'23.0" W, 19 19'44.6" S; Pedreira Mountain (2) coordinates $43^{\circ} 36^{\prime} 42.3^{\prime \prime} \mathrm{W}, 19^{\circ} 18^{\prime} 24.1^{\prime \prime} \mathrm{S}$ and IBAMA (3) coordinates $43^{\circ}$ $36^{\prime} 09.3^{\prime \prime} \mathrm{W}, 19^{\circ} 20^{\prime} 24.0^{\prime \prime} \mathrm{S}$. The three fragments are all of similar size, comparable intermediate successional stage with respect to conservation, and are equivalently isolated by anthropic areas as roads, hotels and pasturelands.

Sampling methods used in this study followed those described by Fernandes \& Price (1988) and Price et al. (1998), specifically, sampling along the trajectory of an "imaginary line," traveled at a natural walking pace over the course of one hour in each of the three forest fragments. Three field-trained personnel carried out the sampling. Samples were acquired during the wet season, Fevereiro (2007), with plants in full leaf. Only lower branches (within $2.0 \mathrm{~m}$ of the forest floor) were sampled. Gall morphospecies were identified based upon their external morphology in combination with the host plant species in which they were found. Usually, galling arthropods induce one or more galls on only one preferred organ of a host plant (Dreger-Jauffret \& Shorthouse 1992; Floate et al. 1996). For example, $95 \%$ of the described cecidomyiid species may be recognized by the gall morphotype formed by their associated host plants (Carneiro et al. 2009). The use of morphospecies to represent the richness of gall-inducing arthropods is widely accepted with numerous applications in the literature [e.g., Price et al. (1998); Cuevas-Reyes et al. (2004); for a review see Carneiro et al. (2009)]. Hence, hereinafter in this article we refer to gall morphotypes as true species.

Host plants and galls were collected and brought back to the laboratory for detailed analysis. All plants and galls were mounted and deposited in the Herbarium (BHCB) of the Departamento de Botânica of the Universidade Federal de Minas Gerais. The collected plants were separated into families and were identified to the lowest taxonomic level possible by specialists. The classification of host plants species followed the classification system proposed by the "Angiosperm Phylogeny Group" (APGII 2003, see too Souza \& Lorenzi 2005). Galls were separated into species and each species was recorded only once in each area to estimate the gall richness. In the laboratory, galls were photographed and categorized according to color, shape, presence or absence of trichomes (glabrous or pubescent), and organ of the host plant in which they were found. Identification of the gall inducer was made whenever possible.

\section{RESULTS}

We recorded 92 galling species induced by arthropods in 19 families, 37 genera and 51 species of host plants in the three fragments of dry forest (Table 1, Figure 1- 6). The family with the highest occurrence of galling species was Fabaceae (24\%, Figure 2-3), followed by Myrtaceae (12\%, Figure 4-5), and Asteraceae (9\%, Figure 1). The genera that supported the highest number of galling species were: Bauhinia (Fabaceae), Myrcia (Myrtaceae), Baccharis (Asteraceae), Celtis (Cannabaceae), and Serjania (Sapindaceae), which combined, hosted 37\% of all galls found. Baccharis dracunculifolia (Asteraceae) and Celtis brasiliensis (Cannabaceae), exhibited the highest number of galling species residing on any single host plant, with both reaching a maximum of five galling species. The number of galling species differed significantly among arthropod taxa. Cecidomyiidae (Diptera) was the most common galling taxa (77\%), followed by Homoptera (6\%), Hymenoptera (4\%), Lepidoptera (4\%), Acarina (2\%), and Coleoptera (1\%). Galls were mainly induced on leaves (63\%) and the most common shape was spherical (30\%). Most galls were found in Fragment 3, which concentrated 54\% of all galling species, followed by Fragment 2 (40\%), and Fragment 1 (35\%). 

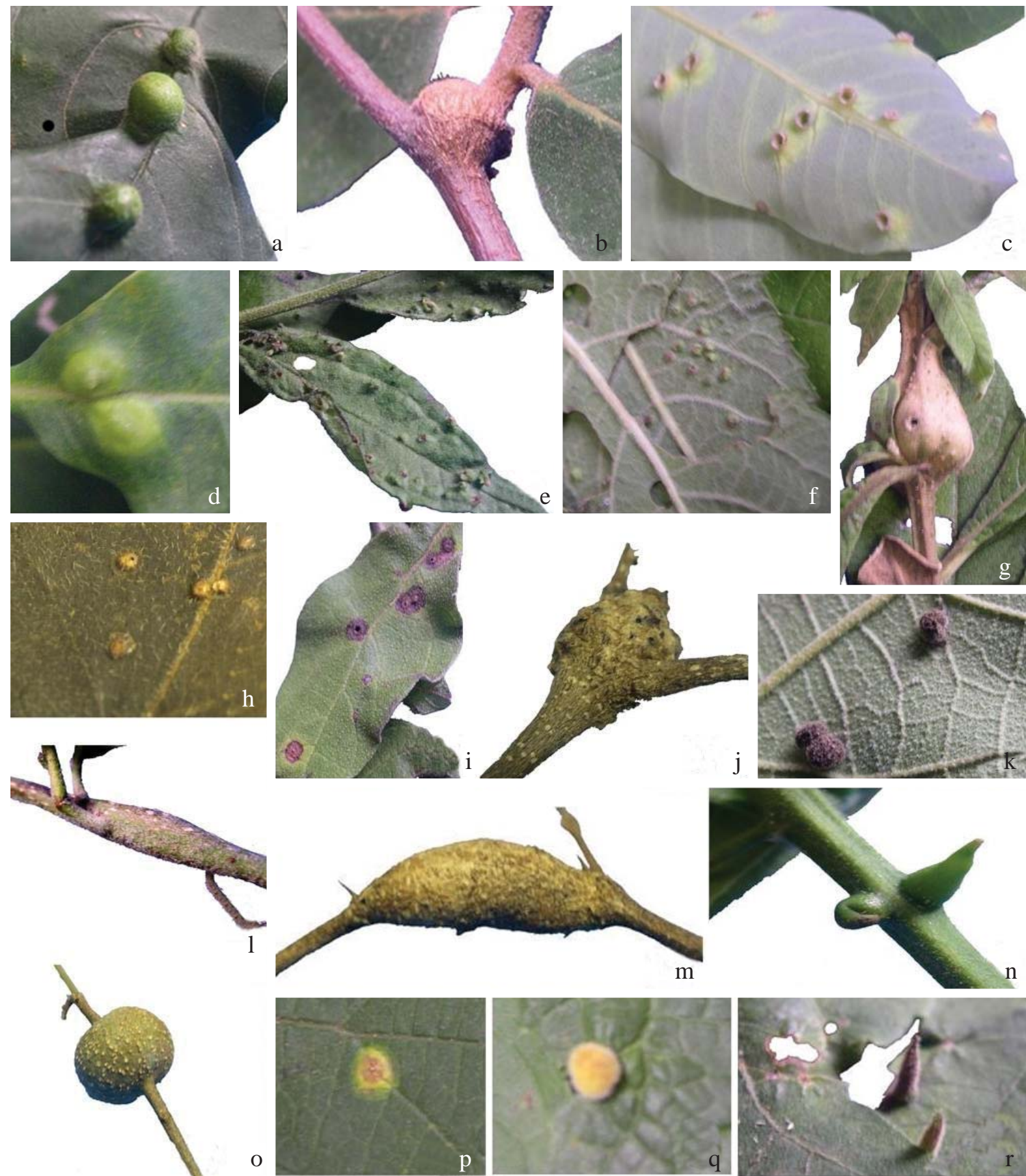

Fig. 1. Galling insect morphospecies in fragments of seasonally Dry Tropical Forest in Serra do Cipó, Minas Gerais, Brazil. Annonaceae (Rollinia laurifolia (a) Rollinia sylvatica (b), Apocynaceae (Aspidosperma cylindrocarpon (c), Aspidosperma pyrifolium (d) Asteraceae (Baccharis sp. (e), Vernonanthura phosphorica (f-g), Boraginaceae (Cordia trichotoma (h-1), Cannabacea (Celtis brasiliensis (m-q), Celtis iguanaea (r).

We recorded $24 \%$ galling species occurring in at least two of the forest fragments, while only $6 \%$ occurred in all three fragments. Only $10 \%$ of galling species identified in this study have had been previously reported. Previously reported galling species include Baccharis dracunculifolia (Table 1) with 5 galls (Fernandes et al. 1996); Celtis brasiliensis (Fig. 1 (o), Table 1 with 1 gall (Fernandes et al. 1997); Terminalia argentea (Fig. 2(c), Table 1 with 1 gall (Fernandes et al. 1997); Bauhinia brevipes (Fig. 3(b), Fig. 3(d), Table 1 with 2 galls (Fernandes, 1998); all found in Cerrado biomes.

\section{DISCUSSION}

A majority of the research on galling organisms occuring in Brazil focuses on two prominent ecosystems, specifically the Cerrado (Fernandes et al. 1988; Gonçalves-Alvim \& 

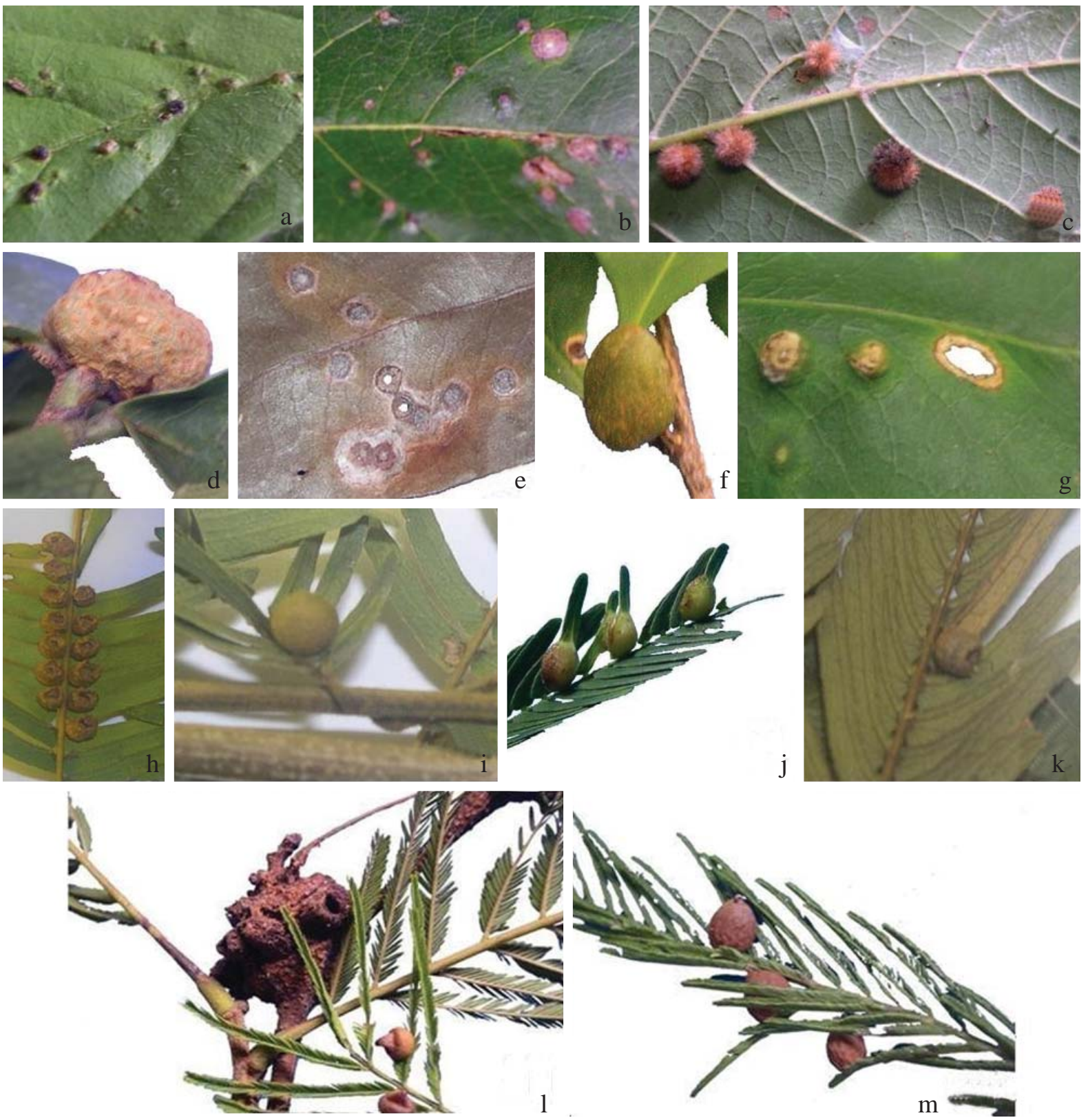

Fig. 2. Galling insect morphospecies in fragments of seasonally Dry Tropical Forest in Serra do Cipó, Minas Gerais, Brazil. Combretaceae (Buchenavia tomentosa (a), Terminalia argentea (b-c), Erythroxylaceae (Erythroxylum citrifolium (d-e), Erythroxylum vacciniifolium (f-g), Fabaceae (Acacia martii (h-i), Acacia sp.1 (j-k), Anadenanthera colubrina (1-m).

Fernandes 2001; Urso-Guimarães et al. 2003; Urso-Guimarães \& Scarelli-Santos 2006) and the Atlantic coastal vegetation called "restinga" (Maia 2001, 2005; Maia et al. 2002). A limited number of studies evaluated galling organisms in Atlantic Rain Forest areas (Fernandes et al. 2001), Pantanal (Julião et al. 2002), and the Amazonian Rain Forest (Julião et al. 2002). Our research represents the first survey of galling organisms performed in areas of STDF. This study reported 92 galling species on 51 species of host plants. Gall-inducers are speciose in the Neotropical region, but despite their richness, little is known about their taxonomy, distribution, host plant and galls. In this study, only $10 \%$ of galling species had already been reported in previous surveys of Cerrado vegetation. Despite high seasonality and consequent leaf loss, and the small, fragmented nature of the sampled STDF, the number of galls found may be considered high when compared with the number of galls reported in surveys performed in other Brazilian biomes (e.g., Fernandes et al. 2001; Gonçalves-Alvim \& Fernandes 2001; Julião et al. 2002; Maia 2001, 2005; Maia et al. 2002; Urso-Guimarães \& Scarelli-Santos 2006). The distribution of galling insects among different herbivore taxa and host plants in this study confirm the Cecidomyiidae as the most common galling taxa in the neotropics (Gagné 1994; Fernandes et al. 2001; Julião et al. 2002; Cuevas-Reyes et al. 2004). 

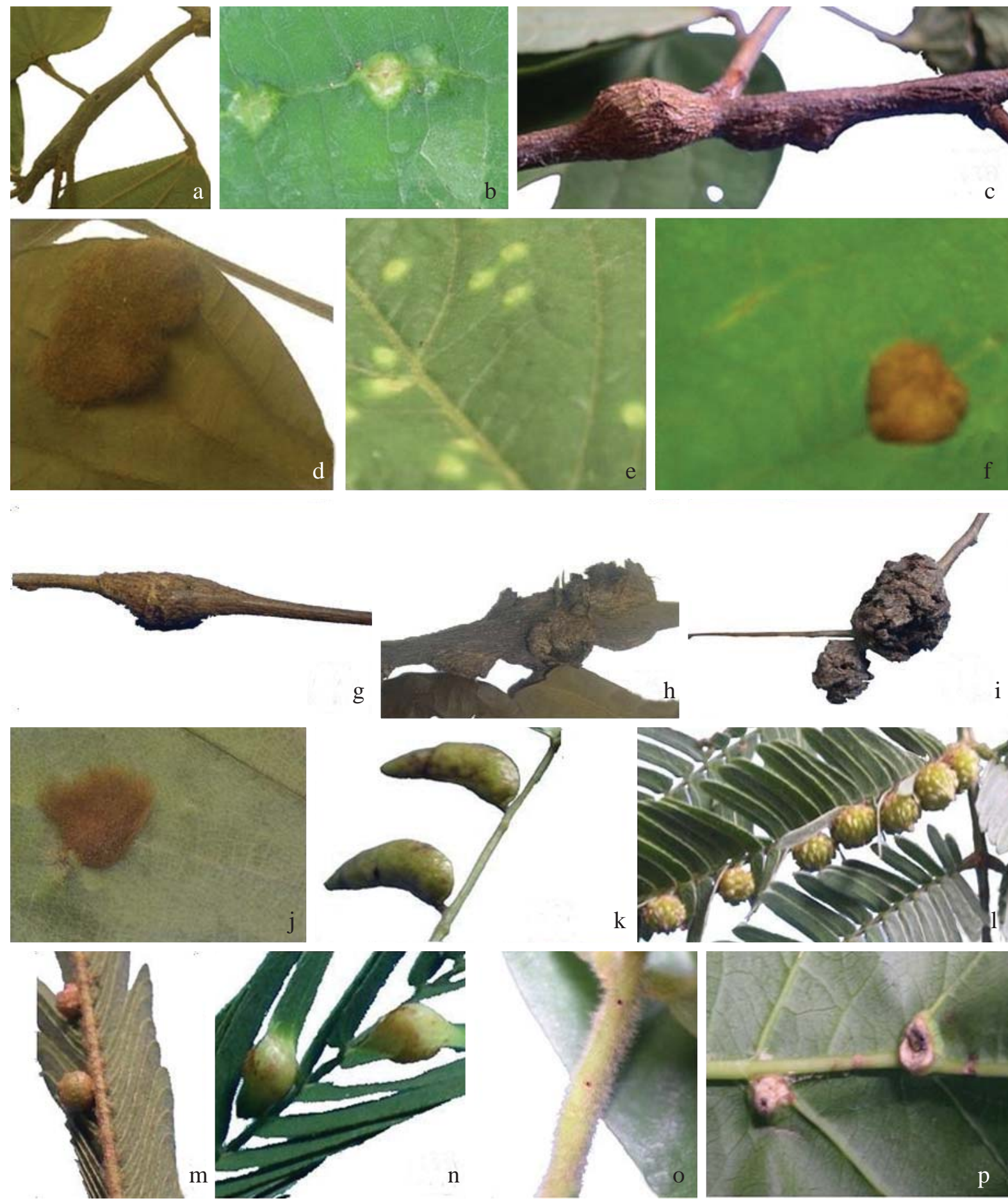

Fig. 3. Galling insect morphospecies in fragments of seasonally Dry Tropical Forest in Serra do Cipó, Minas Gerais, Brazil. Fabaceae - Bauhinia brevipes (a-d), Bauhinia longifolia (e-g), Bauhinia rufa (h), Bauhinia sp (i-j), Copaifera langsdorffii (k), Piptadenia gonoachanta (1-n), Stylosanthes sp. (o), Flacourtiaceae - Casearia rupestris (p).

In recent study carried out in an area characterized by calcareous rocks flanking the Espinhaço, Meguro et al. (2007) found 296 species of vascular plants were found Fabaceae (33 spp.), Euphorbiaceae (18 spp.), Bignoniaceae (13 spp.), Malvaceae (13 spp.), Apocynaceae (11 spp.) and Sapindaceae (11 spp.) as the most representative families. In our survey, the most representative plant families were also the families that supported the most diverse galling. The Fabaceae family possesses the highest variety of subsidiary species detected in STDFs (Pennington et al. 2000; Meguro et al. 2007) and, not unexpectedly, was the taxon with the highest number of plant species sampled $(n=10)$ and with the highest number of 


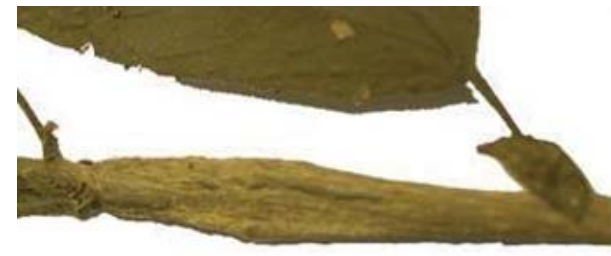

a
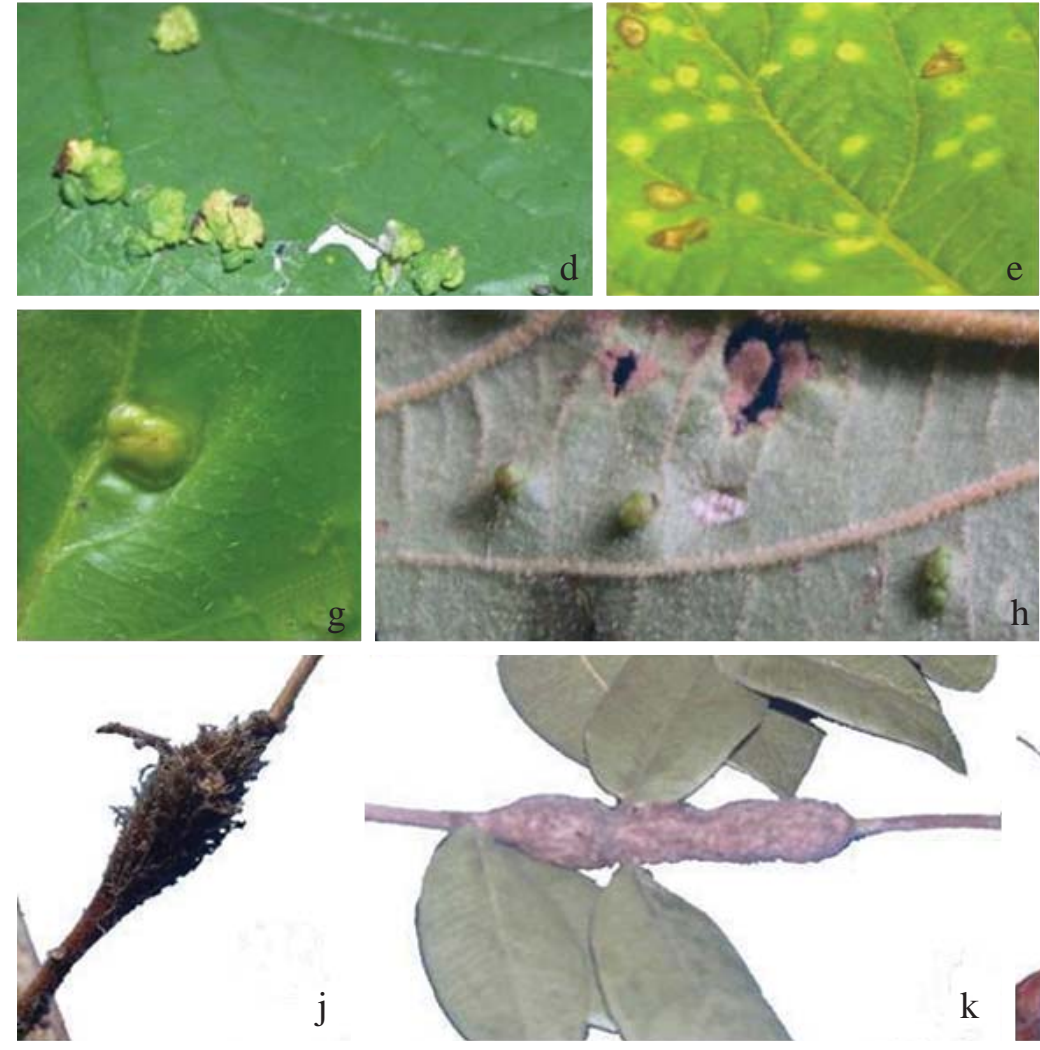

e

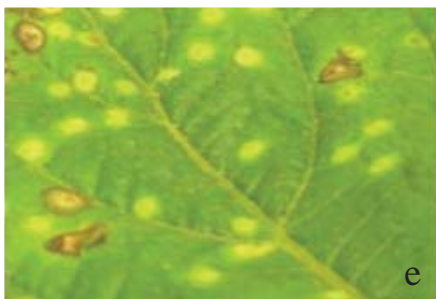

b
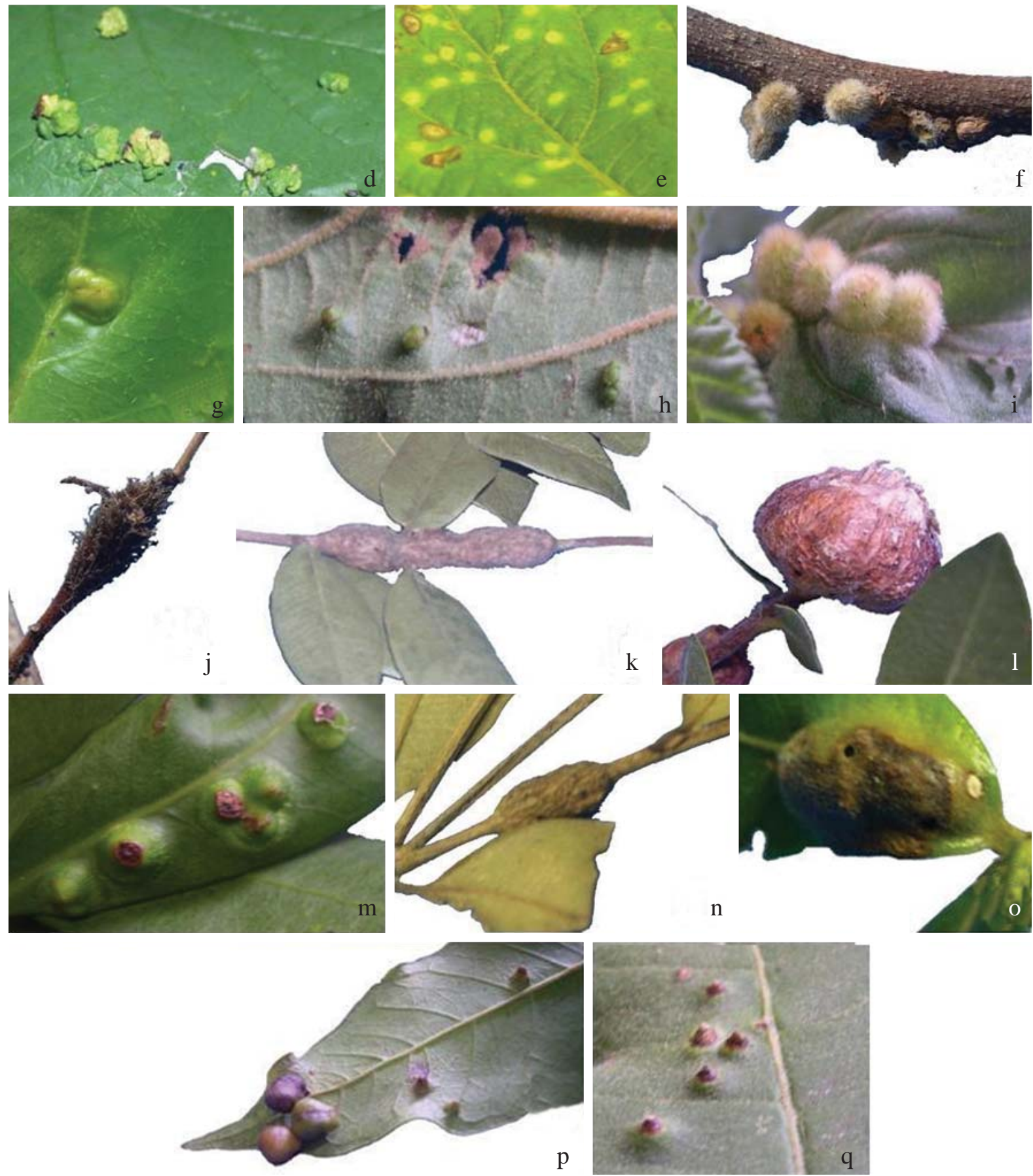

Fig. 4. Galling insect morphospecies in fragments of seasonally Dry Tropical Forest in Serra do Cipó, Minas Gerais, Brazil. Flacourtiaceae Prockia crucis (a), Lamiaceae - Hyptis sp. (b), sp. 1 (c), Malpighiaceae - Banisteriopsis sp. (d-e), Heteropteris sp. (f-g), Malvaceae - Guazuma ulmifolia (h), Sida sp. (i), sp. 1 (j), Myrtaceae - Blepharocalyx salicifolius (k-1), Eugenia sondeliana (m), Myrcia splendens (n-p), Myrcia tomentosa (q). 
Table I. Insec t galls from tropical dry forests, Serra do Cipó, MG.

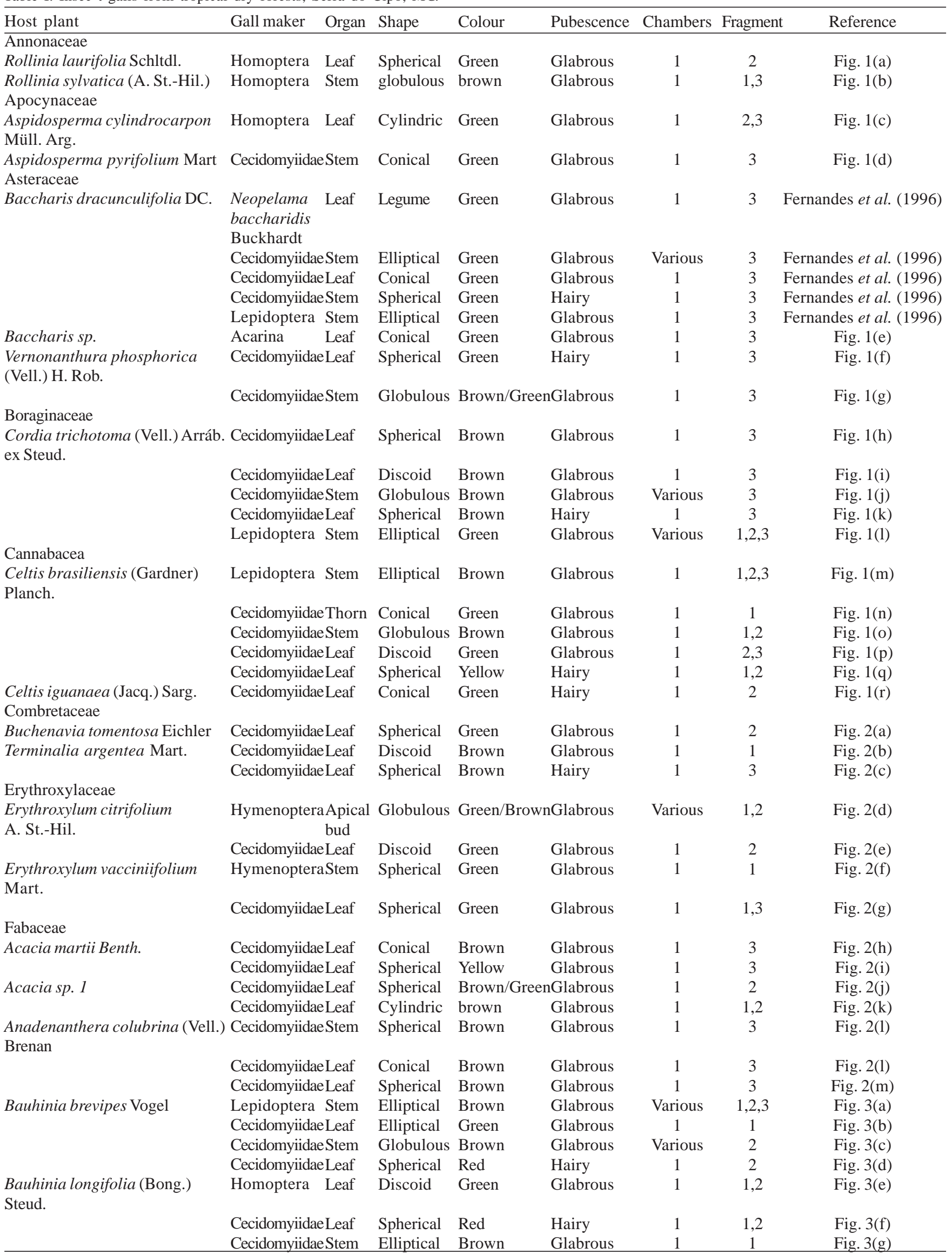


Table I. Cont.

\begin{tabular}{|c|c|c|c|c|c|c|c|}
\hline Host plant & Gall maker Organ & Shape & Colour & Pubescence & Chambers & Fragment & Reference \\
\hline Bauhinia rufa (Bong.) Steud. & CecidomyiidaeStem & Irregular & Brown & Glabrous & Various & $1,2,3$ & Fig. 3(h) \\
\hline \multirow{2}{*}{ Bauhinia sp. } & \multirow{2}{*}{$\begin{array}{l}\text { CecidomyiidaeStem } \\
\text { CecidomyiidaeLeaf }\end{array}$} & Irregular & Brown & Glabrous & Various & 3 & Fig. 3(i) \\
\hline & & Spherical & Red & Hairy & 1 & 3 & Fig. 3(j) \\
\hline $\begin{array}{l}\text { Copaifera langsdorffii (Vogel) } \\
\text { Benth. }\end{array}$ & CecidomyiidaeLeaf & Legume & Green & Glabrous & Various & 2 & Fig. 3(k) \\
\hline \multirow{3}{*}{$\begin{array}{l}\text { Piptadenia gonoacantha } \\
\text { (Mart.) J. F. Macbr. }\end{array}$} & CecidomyiidaeLeaf & Spherical & Green & Hairy & 1 & 2 & Fig. 3(1) \\
\hline & CecidomyiidaeLeaf & Spherical & \multicolumn{2}{|c|}{ Green/BrownGlabrous } & 1 & 2 & Fig. 3(m) \\
\hline & CecidomyiidaeLeaf & Globulous & Yellow & Glabrous & Various & $1,2,3$ & Fig. 3(n) \\
\hline \multicolumn{8}{|l|}{ Flacourtiaceae } \\
\hline Casearia rupestris Eichler & \multirow{2}{*}{$\begin{array}{l}\text { CecidomyiidaeLeaf } \\
\text { CecidomyiidaeStem }\end{array}$} & Conical & Green & Glabrous & 1 & 1 & Fig. 3(p) \\
\hline $\begin{array}{l}\text { Prockia crucis P. Browne ex L. } \\
\text { Lamiaceae }\end{array}$ & & Elliptical & Brown & Glabrous & 1 & 1 & Fig. 4(a) \\
\hline Hyptis sp. & \multirow{2}{*}{$\begin{array}{l}\text { CecidomyiidaeStem } \\
\text { CecidomyiidaeStem }\end{array}$} & Elliptical & Green & Glabrous & 1 & 3 & Fig. 4(b) \\
\hline \multicolumn{6}{|l|}{ Malpighiaceae } & & Fig. 4(c) \\
\hline \multirow{2}{*}{ Banisteriopsis sp. } & Acarina Leaf & Irregular & Green & Glabrous & Various & 1,3 & Fig. 4(d) \\
\hline & Cecidomyiida Leaf & Discoid & Green & Glabrous & Various & 1,2 & Fig. 4(e) \\
\hline \multirow[t]{2}{*}{ Heteropteris sp. } & CecidomyiidaeStem & Spherical & Whitish & Hairy & 1 & 2 & Fig. 4(f) \\
\hline & CecidomyiidaeLeaf & Conical & Green & Glabrous & 1 & 2 & Fig. 4(g) \\
\hline \multicolumn{8}{|l|}{ Malvaceae } \\
\hline Guazuma ulmifolia K. Schum. & \multirow{4}{*}{$\begin{array}{l}\text { CecidomyiidaeLeaf } \\
\text { CecidomyiidaeLeaf } \\
\text { CecidomyiidaeStem }\end{array}$} & Conical & Green & Glabrous & 1 & 3 & Fig. 4(h) \\
\hline Sida sp. & & Spherical & Green & Hairy & 1 & 2 & Fig. 4(i) \\
\hline Sp. 1 & & Elliptical & Brown & Hairy & Various & 3 & Fig. 4(j) \\
\hline \multirow{3}{*}{$\begin{array}{l}\text { Myrtaceae } \\
\text { Blepharocalyx salicifolius } \\
\text { (Kunth) O. Berg }\end{array}$} & & & & & & & \\
\hline & \multirow[t]{2}{*}{ Hymenoptera Stem } & Elliptical & Brown & Glabrous & Various & 3 & Fig. 4(k) \\
\hline & & Globolous & Green & Glabrous & 1 & 3 & Fig. 4(1) \\
\hline \multirow{5}{*}{$\begin{array}{l}\text { Eugenia sonderiana O. Berg } \\
\text { Myrcia splendens (Sw.) DC. }\end{array}$} & CecidomyiidaeStem & Elliptical & Brown & Glabrous & Various & 1 & Fig. 4(m) \\
\hline & CecidomyiidaeStem & Elliptical & Brown & Glabrous & Various & 1,2 & Fig. 4(n) \\
\hline & CecidomyiidaeLeaf & Elliptical & Green & Glabrous & Various & 1,2 & Fig. 4(o) \\
\hline & CecidomyiidaeLeaf & Conical & Green & Glabrous & 1 & 1 & Fig. 4(p) \\
\hline & CecidomyiidaeLeaf & Globulous & Green & Glabrous & Various & 1 & Fig. 4(p) \\
\hline Myrcia tomentosa (Aubl.) DC. & CecidomyiidaeLeaf & Conical & Brown & Glabrous & 1 & 1,2 & Fig. 4(q) \\
\hline & CecidomyiidaeLeaf & Elliptical & Green & Hairy & 1 & 3 & Fig. 5(a) \\
\hline & CecidomyiidaeLeaf & Spherical & Brown & Hairy & 1 & 3 & Fig.5(b) \\
\hline $\begin{array}{l}\text { Psidium sp. } \\
\text { Rubiaceae }\end{array}$ & CecidomyiidaeLeaf & Spherical & Brown & Glabrous & 1 & 2 & Fig. 5(c) \\
\hline Guettarda viburnoides Cham. & Not identified Leaf & Discoid & Green & Glabrous & 1 & 3 & Fig. 5(d) \\
\hline & Not identified Leaf & Elliptical & Green & Glabrous & 1 & 3 & Fig. 5(d) \\
\hline $\begin{array}{l}\text { Sp. } 1 \\
\text { Sapindaceae }\end{array}$ & Not identified Stem & Elliptical & Brown & Glabrous & Various & 1 & Fig. 5(e) \\
\hline Cupania vernalis Cambess. & Not identified Stem & Irregular & Brown & Glabrous & Various & 2 & Fig. 5(f) \\
\hline Serjania sp. 1 & CecidomyiidaeLeaf & Spherical & Green/Red & Glabrous & 1 & $1,2,3$ & Fig. 5(g) \\
\hline & CecidomyiidaeLeaf & Discoid & Green & Glabrous & 1 & 1 & Fig. 5(h) \\
\hline Serjania sp. 2 & CecidomyiidaeLeaf & Elliptical & Green & Glabrous & 1 & 1 & Fig. 5(i) \\
\hline & CecidomyiidaeStem & Elliptical & Green & Glabrous & Various & 3 & Fig. 5(j) \\
\hline & CecidomyiidaeLeaf & Discoid & Green & Glabrous & 1 & 2,3 & Fig. 5(k) \\
\hline $\begin{array}{l}\text { Serjania sp. } 3 \\
\text { Smilacaceae }\end{array}$ & CecidomyiidaeLeaf & Conical & Green & Hairy & 1 & 2 & Fig. 5(1) \\
\hline Smilax sp. 1 & CecidomyiidaeLeaf & Spherical & whitish & Glabrous & 1 & 3 & Fig. 5(m) \\
\hline Smilax sp. 2 & CecidomyiidaeLeaf & Discoid & Green & Glabrous & 1 & 3 & Fig. 5(n) \\
\hline Smilax sp. 3 & CecidomyiidaeStem & Globulous & brown & Glabrous & Various & 3 & Fig. 5(o) \\
\hline Solanaceae & & & & & & & \\
\hline $\begin{array}{l}\text { Capsicum parvifolium Sendtn. } \\
\text { Verbenaceae }\end{array}$ & Coleoptera & Elliptical & brown & Glabrous & Various & 3 & Fig. 6(a) \\
\hline Lantana fucata Lindl. & CecidomyiidaeLeaf & Spherical & Green & Hairy & 1 & 1 & Fig. 6(b) \\
\hline Lippia sp. & CecidomyiidaeLeaf & Cylindric & Green & Hairy & 1 & 3 & Fig. 6(c) \\
\hline & CecidomyiidaeLeaf & Spherical & Green & Hairy & 1 & 3 & Fig. 6(d) \\
\hline $\begin{array}{l}\text { Vochysiaceae } \\
\text { Callisthene major Mart. }\end{array}$ & Homoptera Leaf & Spherical & Green & Glabrous & 1 & 2 & Fig. 6(e) \\
\hline
\end{tabular}



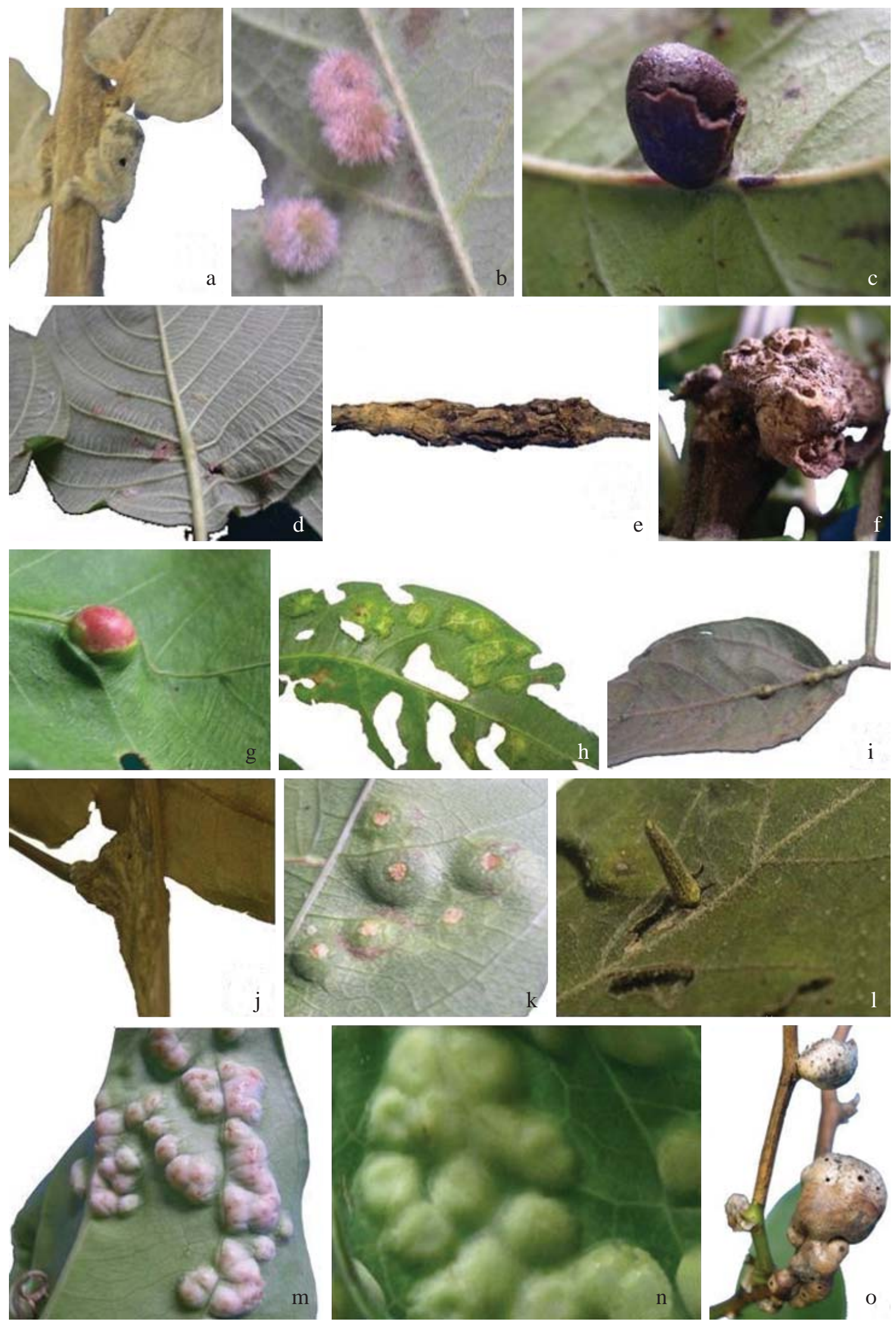

Fig. 5. Galling insect morphospecies in fragments of seasonally Dry Tropical Forest in Serra do Cipó, Minas Gerais, Brazil. Myrtaceae - Myrcia tomentosa (a-b), Psidium (c), Rubiaceae - Guettarda viburnoides (d), sp.1 (e), Sapidaceae - Cupania Vernalis (f), Serjania sp. 1 (g, h), Serjania sp. 2 (i, k), Serjania sp. 3 (1), Smilacaceae - Smilax sp. 1 (m), Smilax sp. 2 (n), Smilax sp. 3 (o). 

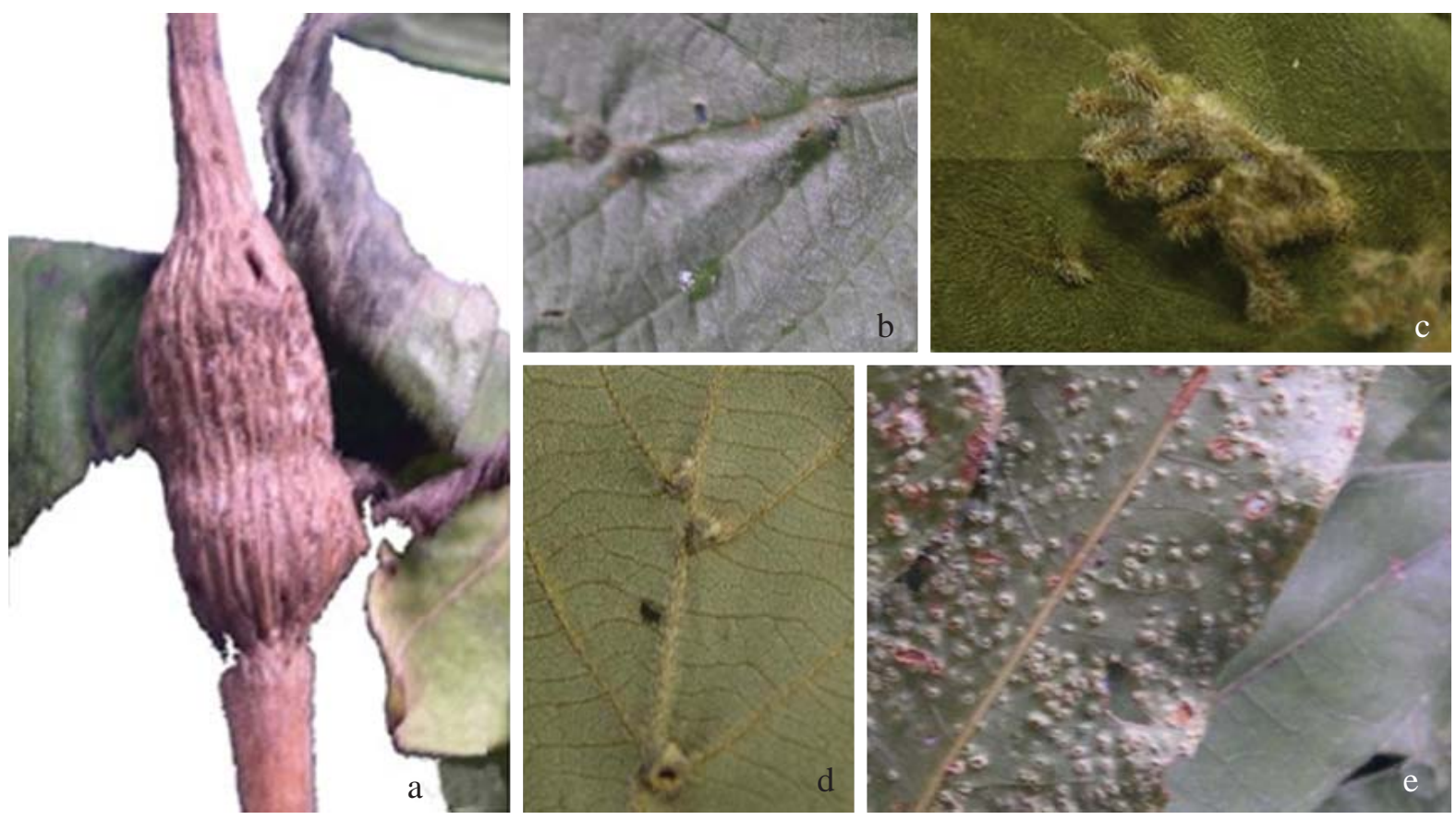

Fig. 6. Galling insect morphospecies in fragments of seasonally Dry Tropical Forest in Serra do Cipó, Minas Gerais, Brazil. Solanaceae Capisicum parvifolium (a), Verbenaceae - Lantana fucata (b), Lippia sp. (c-d) Vochysiaceae - Callisthene major (e).

galling species $(\mathrm{n}=23)$. The same pattern was observed for the a variety of biomes, including Cerrado (Gonçalves-Alvim \& Fernandes 2001), rupestrian fields (Maia \& Fernandes 2004), and Atlantic rain forests (Fernandes et al. 2001), where families with the highest number of plant species supported the highest number of galling species (see also Fernandes 1992; Mendonça 2007). This pattern did not hold for the Asteraceae and Myrtaceae families, respectively the second and third most productive galling species following Fabaceae found in this study. Future field studies on the ecological mechanisms that shape galling species richness within STDFs will allow us to better contrast the specific vegetations studied so far.

Given the intense human pressure on the SDTFs (SánchezAzofeifa et al. 2005), the high richness of galling arthropods and implied floral host diversity found in this survey indicates the need for an increased effort to understand the implications of such diversity in these vulnerable ecosystems. The distribution pattern of one host plant species and its availability to galling arthropods present in this study (Anadenanthera colubrina), as well as other arboreal species, follows the paradigm of the Pleistocenic arc. This concept uses mapping of the "Seasonal Tropical Forests Range", which suggests that the distribution of Brazilian STDFs arose during Pleistocene era (Prado 2005). Host species occur on a continental scale and range from the Brazilian Northeast to the Brazilian Pantanal (Prado 2005). Perhaps interesting avenues for research will be provided by the study of host plants and their associated galling arthropods widely distributed in the disjunct STDFs across the Americas.
Acknowledgments. We thank the Parque Nacional da Serra do Cipó, Hotel Rancho Cipó and Reserva Natural Vellozia for logistical support. We appreciate the cooperation of specialists Dr. Ary Teixeira de Oliveira Filho for the identification of plant species. We also thank the University of Alberta and CNPq (309633/2007-9) for financial support. This is contribution 21 of the Tropi-Dry research network. This work was carried out with the aid of a grant from the Inter-American Institute for Global Change Research (IAI) CRN II \# 021, which is supported by the US National Science Foundation (Grant GEO- 0452325).

\section{REFERENCES}

APGII. 2003. An update of the Angiosperm phylogeny group classification for the orders and families of flowering plants: APGII. Botanical Journal of the Linnean Society 141: 399-436.

Carneiro, M. A. A.; C. S. A. Branco; C. E. D. Braga; E. D. Almada; M. B. M. Costa; V. C. Maia \& G. W. Fernandes. 2009. Are gall midge species (Diptera, Cecidomyiidae) host-plant specialists? Revista Brasileira de Entomologia 53: 365-378.

Cuevas-Reyes, P.; M. Quesada; P. Hanson; R. Dirzo \& K. Oyama. 2004. Diversity of gall-inducing insects in a Mexican tropical dry Forest: the importance of plant species richness, life forms, host plant age and plant density. Journal of Ecology 92: 707-716.

Dalbem, R. V. \& M. S. Mendonça. 2006. Diversity of galling arthropods and host plants in a subtropical forest of Porto Alegre, Southern Brazil. Neotropical Entomology 35: 616-624.

Dreger-Jauffret, F. \& J. D. Shorthouse. 1992. Diversity of gall-inducing insects and their galls, p. 8-33. In: J. D. Shorthouse \& O. Rohfritsch (eds.). Biology of insect-induced galls. Oxford, Oxford University Press, xi+285 p.

Eiten, G. 1978. Delimitation of Cerrado concept. Vegetatio 36: 169178.

Espírito-Santo, M. M. \& G. W. Fernandes. 2007. How many species of gall-inducing insects are there on earth, and where are there? Annals of the Entomological Society of America 100: 95-99. 
Fernandes, G. W. 1998. Hypersensitivity as a phenotypic basis of plant induced resistance against a galling insect (Diptera: Cecidomyiidae). Population Ecology 27: 260-267.

Fernandes, G. W. 1992. Plant family size and age effects on insular gall-forming species richness. Global Ecology and Biogeography letters 2: 71-74.

Fernandes, G. W.; G. R. Julião; R. C. Araújo; S. C. Araújo; J. A. Lombardi; D. Negreiros \& M. A. A. Carneiro. 2001. Distribution and morphology of insect galls of the Rio Doce Valley, Brazil. Naturalia 26: 211-244.

Fernandes, G. W. \& P. W. Price. 1988. Biogeographical gradients in galling species richness: tests of hypotheses. Oecologia 76: 161167.

Fernandes, G. W. \& P. W. Price. 1991 Comparison of tropical and temperate galling species richness: the roles of environmental harshness and plant nutrient status, p. 91-115. In: P. W. Price; T. M. Lewinsohn; G.W. Fernandes \& W. W. Benson (eds.). Plantanimal interactions: evolutionary ecology in tropical and temperate regions. Wiley \& Sons, xiv+637 p.

Fernandes, G. W.; R. C. Araújo; S. C. Araújo; J. A. Lombardi; A. S. Paula; R. Loyola Júnior \& T. G. Cornelissen. 1997. Insect galls from savanna and rocky fields of the jequitinhonha valley, Minas Gerais, Brazil. Naturalia 22: 221-244.

Floate, K. D.; G. W. Fernandes \& J. A. Nilsson. 1996. Distinguishing intrapopulacional categories of plants by their insect faunas: galls on rabbitbrush. Oecologia 105: 221-229.

Gagné, R. J. 1994. The gall midges of the region neotropical. Ithaca, Comstock, xiv $+352 \mathrm{p}$.

Giulietti, A. M.; N. L. Menezes; M. M. Pirani \& M. G. L. Wanderley. 1987. Flora da Serra do Cipó, Minas Gerais: caracterização e lista das espécies. Boletim de Botânica 9: 1-151.

Gonçalves-Alvim, S. J. \& G. W. Fernandes. 2001. Biodiversity of galling insects: historical, community and habitat effects in four neotropical savannas. Biodiversity and Conservation 10: 79-98.

Julião, G. R.; M. E. C. Amaral \& G. W. Fernandes. 2002. Galhas de insetos e suas plantas hospedeiras no Pantanal sul-mato-grossense. Naturalia 27: 47-74.

Julião, G. R.; E. M. Venticinque; G. W. Fernandes \& J. E. Kraus. 2005. Richness and abundance of gall-forming insects in the Mamirauá Varzea, a flooded Amazoniam forest. Uakari 1: 39-42.

Lara, A. C. F. \& G. W. Fernandes. 1996. The highest diversity of galling insects: Serra do Cipó, Brazil. Biodiversity Letters 3: 111-114.

Maia, V. C. 2001. The gall midges (Diptera, Cecidomyiidae) from three restingas of Rio de Janeiro State, Brazil. Revista Brasileira de Zoologia 18: 583-629.

Maia, V. C. 2005. Catálogo dos Cecidomyiidae (Diptera) do estado do Rio De Janeiro. Biota Neotropica 5: 1-26.

Maia, V. C. \& G. W. Fernandes. 2004. Insect galls from Serra de São José (Tiradentes, MG, Brazil. Revista Brasileira de Biologia 6: 423-445.

Maia, V. C.; M. A. P. Azevedo \& M. S. Couri. 2002. New contribution to the knowledge of the gall midges (Diptera, Cecidomyiidae) from the restinga of Barra de Maricá (Rio de Janeiro, Brazil). Studia Dipterologica 9: 447-452.

Mani, M. S. 1964. The ecology of plant galls. Dr. Junk, The Hague, $\mathrm{xii}+434$

Meguro, M.; Pirani, J. R.; Mello-Silva, R. \& I. Cordeiro. 2007. Composição florística e estrutura das florestas estacionais decíduas sobre calcário a oeste da Cadeia do Espinhaço, Minas Gerais, Brazil 25: 147-171.

Mendonça, M. S. 2007. Plant diversity and galling arthropod diversity searching for taxonomic patterns in an animal-plant interaction in the neotropics. Boletín Sociedad Argentina Botánica 42: $347-357$
Nascimento, A. R. T.; J. M. Felfili \& E. M. Meirelles. 2004. Florística e estrutura da comunidade arbórea de um remanescente de Floresta Estacional Decidual de encosta, Monte Alegre, GO, Brasil. Acta Botanica Brasílica 18: 659-6.

Nyman, T. \& R. Julkunen-Tiitto. 2000. Manipulation of the phenolic chemistry of willows by gall-inducing sawflies. Proceedings National Academic of Science 97: 13184-13187.

Oliveira, J. C. \& V. C. Maia. 2005. Ocorrência e caracterização de galhas de insetos na restinga de Grumari (Rio de Janeiro, RJ, Brasil) Arquivos do Museu Nacional 63: 669-675.

Pennington, R. T.; D. A. Prado \& C. Pendry. 2000. Neotropical seasonally dry forests and quaternary vegetation changes. Journal of Biogeography 27: 261-273.

Prado, D. E. 2000. Seasonally dry forests of Tropical South America: from forggottem ecosystems to a new phytogeographic unit Edinburgh Journal of Botany 57: 437-461.

Prado, D. 2003. As caatingas da América do Sul, p. 3-73. In: I. R. Leal, M.; J. Tabarelli \& M. C. Silva (eds.). Ecologia e conservação da Caatinga. Recife, Editora Universitária, viii+822 p.

Price, P. W.; G. W. Fernandes \& G. L. Waring. 1987. Adaptative nature of insect galls. Environmental Entomology 16: 15-24.

Price, P. W.; G. L. Waring \& G. W. Fernandes. 1986. Hypotheses on the adaptive nature of galls. Proceedings of the Entomological Society of Washington 88: 361-363.

Price, P. W.; G. W. Fernandes; A. C. F. Lara; J. Brawn; D. Gerling; H. Barrios; M. G. Wright; S. P. Ribeiro \& N. Rothcliff. 1998. Global patterns in local number of insect galling species. Journal of Biogeography 25: 581-591.

Raman, A. 2007. Insect-induced plant galls of India: unresolved questions. Current Science 92: 748-757.

Ratter, J. A.; G. P. Askew; R. Montgomery \& D. R. Gifford. 1978 Observations on forests of some mesotrophic soils in central Brazil. Revista Brasileira de Botanica 1: 47-58.

Ribeiro, J. M. \& B. M. T Walter. 1998. Fitofisionomias do bioma Cerrado, p. 89-166. In: S. M. Sano \& S. P. Almeida (eds). Cerrado: flora e ambiente. Planaltina, Embrapa-CPAC, vi+556.

Rizzini, C. T. 1997. Tratado de fitogeografia do Brasil - aspectos ecológicos, sociológicos e florísticos. Rio de Janeiro. Âmbito Cultural Edições, vii+747 p.

Sánchez-Azofeifa, G. A.; M. Quesada; J. P. Rodríguez; J. M. Nassar; K. E. Stoner; A. Castillo; T. Garvin; E. L. Zent; J. C. Calvo-Alvarado; M. Kalacska; L. Fajardo; J. A. Gamon \& P. Cuevas-Reyes. 2005 Research priorities for Neotropical dry forests. Biotropica 37: $477-485$

Souza, V. C. \& H. Lorenzi. 2005. Botânica Sistemática: guia ilustrado para identificação das famílias de Angiospermas da flora brasileira, baseado em APG II. Nova Odessa, Instituto Plantarum, ix $+640 \mathrm{p}$.

Stone, G. N. \& K. Schönrogge. 2003. The adaptive significance of insect gall morphology. Trends Ecology and Evolution 18: 512 522.

Urso-Guimarães, M. V. \& C. Scarelli- Santos. 2006. Galls and gall makers in plants from the Pe-Gigante Cerrado Reserve, Santa Rita do Passa Quatro, SP, Brazil. Brazilian Journal of Biology 66 : $357-369$.

Urso-Guimarães, M. V.; C. Scarelli-Santos \& A. C. Bonifácio-Silva. 2003. Occurrence and characterization of entomogen galls in plants from natural vegetation areas in Delfinópolis, MG, Brazil. Brazilian Journal of Biology 63: 705-715.

Weis, A. E.; R. Walton \& C. L. Crego. 1988. Reactive plant tissue sites and the population biology of gall makers. Annual Review of Entomology 33: 467-486.

Received 20/06/2008; accepted 29/01/2009 